International Journal of Business Management and Economic Review

Vol. 4, No. 05; 2021

ISSN: 2581-4664

\title{
APPLICABILITY OF UPPSALA MODEL OF INTERNATIONALIZATION IN THE MODERN BUSINESS ENVIRONMENT
}

\author{
Pushpa Rani \\ Doctoral Student (International Business) Oulu Business School, University of Oulu Department of Marketing, \\ Management and International
}

http://doi.org/10.35409/IJBMER.2021.3315

\begin{abstract}
The recent technological advancements have played an essential role in enhancing globalization and internationalization. As a result, many firms are investing to leverage these technological advancements to expand their target audience and ultimately access foreign markets. It is important to explain that different organizational entities tend to have different approaches to internationalization. However, this report aims to examine how modern firms are using the Uppsala model during the internationalization process. It wishes to determine the efficacy of the Uppsala model, as well as the impacts of the Uppsala model on international entrepreneurship. This conceptual research can be helpful to the managers and policy makers (Huo \& Hung, 2015) when they are planning to expand business globally by using appropriate Uppsala model.
\end{abstract}

Keyword: Uppsala model, international entrepreneurship, internalization process theory, business network theory.

\section{INTRODUCTION}

With no doubt, effective implementation and successful integration of the internationalization process is heavily dependent on market research, SWOT (strengths, weaknesses, opportunities, and threats) analysis and other integrated tools (Sandberg, 2012) that detect variation at different levels. However, it is also dependent on the models adopted by individual firms to expand the target market. As the business expand nationally or internationally, the challenges, problems and organizational tasks start to increase (Mueller et al., 2012). There are myriad eternal factors such as un-predictable political environments, variables foreign exchange rates, different cultures, unfavorable economic-policies, and social factors that may influence the internationalization process (Jafari-Sadeghi et al., 2020). Additionally, there several internationalization theories which try to explain the critical view of Uppsala model in modern times and why there are international activities (Hombercher, 2014).

This paper aims to examine the applicability of the Uppsala model in the internationalization process, particularly in the modern business environment. This is because rapid advancement of technology and globalization has rapidly transformed and speeded up the internationalization process (Kalinic, \& Forza, 2012). As a result, the world has become more homogenous, and the psychic distance has ultimately reduced between the countries (Ojala \& Tyrväinen, 2009). According to Boone's (2018) findings, firms tend to have natural tendency of expanding after reaching a specific threshold. He explains that internationalization process tends to begin once 


\section{International Journal of Business Management and Economic Review}

Vol. 4, No. 05; 2021

ISSN: 2581-4664

organizational leaders identify and international opportunity. On the other hand, Beugelsdiik et al. (2018) highlight that Uppsala model plays an important role in the defining the internationalization process of business through knowledge acquired and experience. The model is appropriate for SMEs and act as framework that guide firms to expand their market reach. Nonetheless, it is recommended for modern firms to develop a plan for internationalization that effectively meets the needs of the target market before triggering the expansion process

\section{Background}

According to Autio (2017), the demand for business expansion has drastically increased, making entrepreneurs more conscious about evaluating the internationalization practices and modifying their respective business models. A good entrepreneur is the one who knows how to use entrepreneurial skills well in uncertain situation and is ready to take risks, identify opportunities (Tang et al., 2012), be innovative and use resources creatively (Klerk, 2014; Mueller et al., 2012). The main objective of most entrepreneurs is to expand their organizational entities and consequently gain access to foreign markets. However, different entrepreneurs tend to have different perspectives of organizational opportunities, strategies, processes, and internationalization approaches (Belitski \& Heron, 2017).

Based on Gabrielsson et al's (2014) findings, international entrepreneurship refers to the mixture of innovative, proactive, and risk-seeking behaviour across national borders. They explain that international entrepreneurs tend to have a unique ability of supporting and legitimizing their business globally. They are also innovative and effective leaders (Malecki, 2018) who play a significant role in motivating, directing, and leading their people to work towards helping their respective firms to expand to the international markets (Ruzzier, Rus \& Douglas, 2015).

Cunningham et al. (1991) explains that there is a huge need for entrepreneurs to learn from the experiences of the failing entrepreneurial ventures and ultimately develop a suitable internalization model that suits the need of their target markets. As almost every company or enterprise is affecting by at least some kind of international challenges (Kalinic et al., 2012). In the beginning, the companies do not expand due to lack of knowledge about foreign market and foreign operations (Welch et al., 2016), culture and the tendency to avoid uncertainties (Hombercher, 2014). International entrepreneurs are expected to draw lessons from existing multinational companies that have managed to use suitable models to access foreign markets. According to Machado (2016), successful international entrepreneurs are the ones that recognize an existing opportunity, take risk, and provide a clear direction which firms can take to expand to other markets. These attributes help the firms to successfully cope with the challenges while expanding into foreign market (Kraus et al., 2016). However, these attributes can be applicable by starting the right business at the right time (Kularia, 2016).

The purpose of this paper is to examine the applicability of the Uppsala model in the internationalization process, particularly in the modern business environment. It seeks to explore how existing firms can leverage Uppsala model to build international brands with great competitive margins and market share. Furthermore, it aims to examine some of the scholarly sources that explains the role of Uppsala model in international entrepreneurship. This is because the Uppsala model works well with the existing tools and often acts as a framework for 


\section{International Journal of Business Management and Economic Review}

Vol. 4, No. 05; 2021

ISSN: 2581-4664

expanding to foreign markets (Hombercher, 2014), particularly for small-scale enterprises (SMEs). The model can also be used to align a company's output with the needs of the foreign market. It allows entrepreneurs to leverage organizational resources including human capital to accelerate a firm's access to an international market.

\section{THEORETICAL BACKGROUND}

\section{Internationalization process}

Hollsten (2016) explains that internationalization process refers to the practice of providing goods and services that meet the needs of the foreign markets. It plays crucial role in helping companies and businesses to widen their business reach to international markets. Many existing enterprises have attempted to use the Uppsala model to expand their businesses to foreign markets. Uppsala model appears to be an appropriate tool for guiding firms to discover and exploit new ideologies and opportunities in the global market (Baker et al., 2005; Ucbasaran, Wright, \& Westhead, 2010). This is because it puts more emphasis on steady growth, strategic thinking, innovation, and risk management. Entrepreneurship is a mechanism by which society converts informational into doing business (Shane \& Venkataraman, 2000: 219). Therefore, it is important to highlight that the presence of cutting-edge technologies in the modern business environment is largely responsible for promoting globalization. As a result, many firms are looking to integrate the Uppsala model with the latest technologies to reap the maximum benefits of globalization (Cavusgil \& Knight, 2015). This integration has played a significant role in streamlining the internalization process and reducing the costs that are involved in the process.

In general, it is apparent that most business entities regardless of their sizes are concerned with internationalization since it contributes to their growth and development in the competitive market environment (Cavusgil \& Knight, 2015). According to Johanson and Vahlne (2009), the internationalization process has specific defining characteristics. Therefore, it is essential to develop a business model that clearly fits these defining characteristics. Johanson and Vahlne (2009) further explain that markets are networks of relationships where businesses come together in intricate invisible patterns. As a result, the entrepreneurs with relevant networks in the foreign markets are called insiders. For a company to expand to a foreign market, the insider needs to build commitment and trust with all the agents that are associated with the foreign market. Appropriate networking, as well, as the adoption of the appropriate model results in successful internationalization. It is also something that brings value to the relationship between companies and consumers from the target market.

\section{Internationalization of new ventures}

Prior to the 1980s, there were no theories explaining the concepts of the internationalization process (McDougall, 1989; Wach, 2015). This is because globalization was still a very new concept and there were very limited tools and resources that could support and sustain the globalization process. However, there exists numerous tools and resources in the current business environment that promotes the internationalization process.

Firms grow in different phases during which they address different sets of problems and challenges throughout their lifecycles (Gabrielsson et al., 2014). Therefore, entrepreneurs can 


\section{International Journal of Business Management and Economic Review}

Vol. 4, No. 05; 2021

ISSN: 2581-4664

leverage the Uppsala model to adapt to the ever-changing trends in the global market and also to effectively respond to the technological shifts. Uppsala model can be used to manage differentiation, legitimize global business, and also create a supportive environment for international and transnational trading (Zucchella \& Magnani, 2016). Entrepreneurs are constantly looking to find ways of expanding their business entities, recognizing opportunities in the market (Saskia De Klerk, 2014) and widening their profit margins. Therefore, it is highly important for them to adopt measures and approaches that improves their innovative capacity and allows them to meet the needs of the foreign markets. According to Zander et al. (2015), Uppsala model can be used to guide firms to establish alliances, make contacts, hire diverse and better technical talent, access global resources, and most importantly harness country-specific benefits (Coviello \& Jones, 2015). The Uppsala model not only provides a roadmap for international entrepreneurs to expand to a foreign market but also allows these entrepreneurs to identify emerging opportunities and ultimately find ways of exploiting those opportunities.

Figure. 1. (The entrepreneurial sources of opportunities through discovery, evaluation and exploitation of the opportunities to create the value).

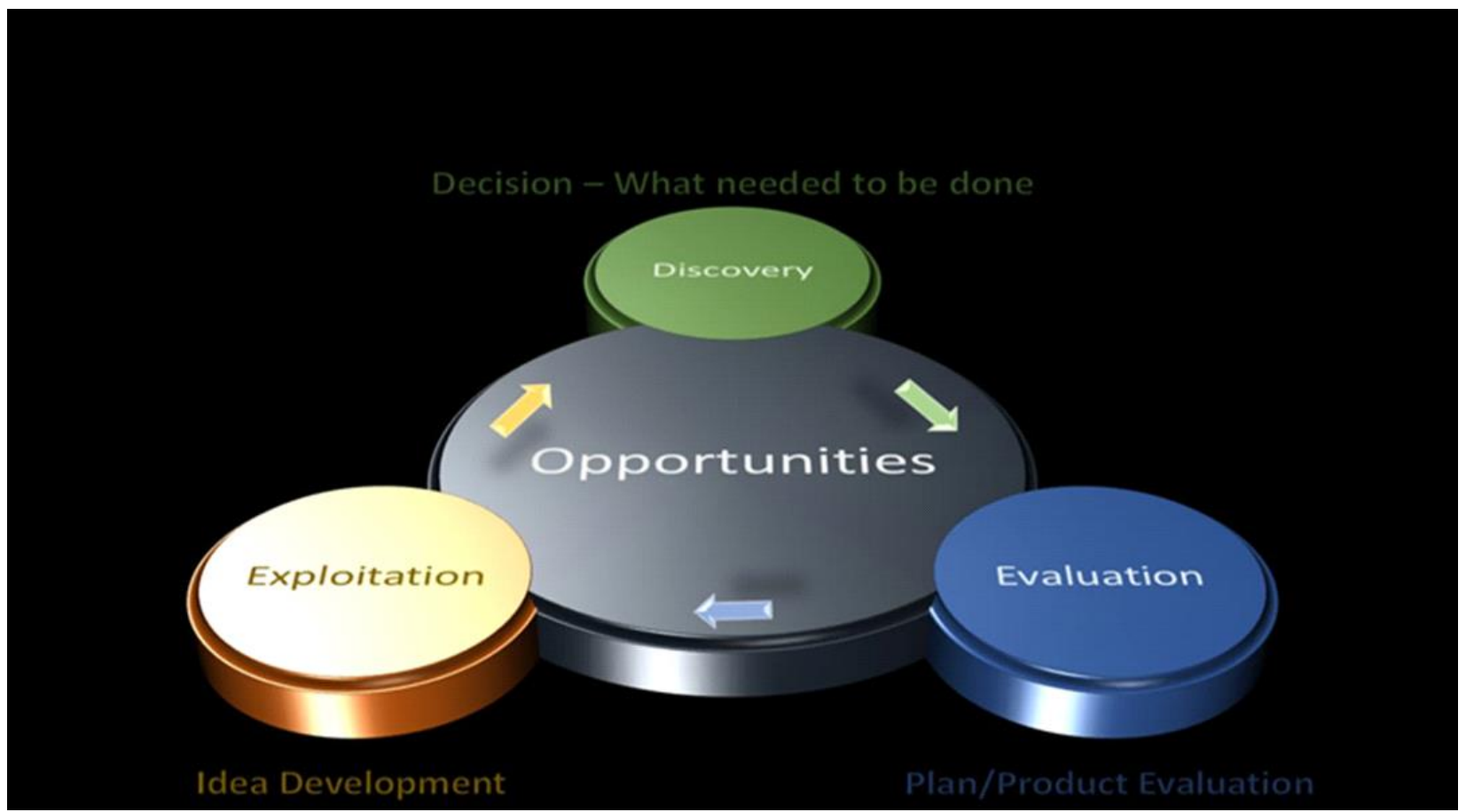

\section{Internationalization through entrepreneurship: process and theory}

The role of entrepreneurship today getting known rapidly so it is important to understand how to recognize and develop the new entrepreneurial opportunities (Tang et al., 2012). International entrepreneurship is about acting on opportunities globally (Mainela, Puhakka \& Sakari, 2014; Oviatt \& McDougall, 2005; Rueber et al., 2017) and has become increasingly valuable in the recent years due to the rapid advancement of technology. In the modern business environment, entrepreneurs can leverage existing technological platforms to remotely communicate or collaborate with other people (Rani, 2019). In Shane and Venkataraman's (2000) framework, to 


\section{International Journal of Business Management and Economic Review}

Vol. 4, No. 05; 2021

ISSN: 2581-4664

succeed in discovering, evaluating and exploiting new entrepreneurial opportunities, entrepreneur should make the use of new technologies and ignores the unnecessary socialized (Lee \& Williams, 2007). This process of the framework is the key function of entrepreneurship that recognizes the existing technologies and implements the growth opportunities across the national borders (Mainela, Puhakka \& Servais, 2014; Fadahunsi, 2012; Baker et al., 2005). The existing technologies have blurred boundaries created by differences in geographical locations. Regardless of the existence of these technologies, Uppsala model has continued to be more relevant since it is used by many firms to determine the risks and tapping into entrepreneurial opportunities (Kauppinen \& Puhakka, 2010; Hindle, 2004) involved in the business expansion (Rani, 2019; Butuner, 2016; Hsieh et al., 2007; Birkinshaw \& Ridderstråle, 1999). One of the cores of benefit of this model, it has continually played a significant role in assisting firms to manage their risks and focus on gradual growth when expanding to foreign markets. According to Reuber et al. (2018), international entrepreneurship is driven by entrepreneurs who aim to develop something with longevity and has a competitive edge on the global market. Therefore, they encourage entrepreneurs to take advantage of the existing models including the Uppsala model, as well, as the existing technologies to expand to their enterprises.

\section{Internationalization process theory}

International process theory explains that companies tend to invest and expand in nations with a short psychic distance to the home nation (Autio, 2017). Reuber et al. (2018) explains that many business entities tend to prefer to extend their business operations to countries that have the same business and cultural characteristics to the home country. These characteristics range from business practices, market structure, language, economic conditions, politics, culture, and legislation. Internationalization process theory views the business expansion process as a series of steps that should be systematically completed. It instils firms with confidence to adequately prepare and ultimately meet the needs of the target foreign markets (Andersson, 2006). It also presents internationalization as a self-resourcing feedback process where firms develop confidence by first engaging in foreign markets that are similar to their domestic markets and then using the newfound confidence and experience to expand to markets with longer psychic distance.

The internalization process theory highlights that internationalization can be viewed as an incremental process, based on the geographic location (Ratten et al., 2017; Pukall \& Calabro, 2014). This is because firms tend to progressively accumulate market experience as they continue expanding to other foreign markets. Uppsala model plays an important role in allowing business entities to evaluate and exploit emerging opportunities during the internationalization process (Ciszewska-Mlinaric, 2016). One of the major advantages of internalization process theory is that it guides entrepreneurs to develop a plan of action regarding the development of international relations and also allows firms to understand the potential obstacles that are likely to hinder organizational success in the foreign market (Gabrielsson et al., 2014).

Internalization process theory recommends the need to collect adequate data regarding the target foreign market before launching the expansion process. This theoretical framework highlights that it is important to learn about the values and needs of the foreign customers and ultimately establish trust with them (Johanson \& Vahlne, 2002) to improve market performance (Aulakh et 


\section{International Journal of Business Management and Economic Review}

Vol. 4, No. 05; 2021

ISSN: 2581-4664

al., 1996). Lack of knowledge of the target market (Hombrecher, 2014) may pose significant risks on the internationalization process. It can hinder a firm from successfully meeting the needs of the target consumers (Lehtoranta, Rilla \& Loikkanen, 2012). Internationalization process theory recommends that there is a huge need for business entities and entrepreneurs to follow the due procedures when looking to gain access to a foreign market. It suggests that it is a good idea the modern companies to start with foreign markets with short psychic distance before proceeding to the ones with longer psychic distance. Means, according to Uppsala model, at the initial stage of internationalization, the firms should enter most familiar markets (less distance) and then gradually 'move on to less familiar territories (long distance)' (Dunning, 2001, p. 40; Ciszewska-Mlinarič \& Trąpczyński, 2016).

\section{Uppsala model and business network theory}

The Uppsala model of internationalization was first developed by Johanson and Vahlne back in 1977 and has since been widely used to guide the internationalization process. The initial Uppsala model focused on the market commitment and market knowledge. Galkina and Chetty (2015) suggested that firms should first acquire knowledge of the target foreign markets before proceeding to commit to those markets (Welch et al., 2014, p. 8; Kalinic et al., 2012). The initial concepts of the Uppsala model expected firms to start the internalization process from the neighbouring countries before moving gradually to distant markets (Ciszewska-Mlinarič et al., 2016).

However, over time, scholars noted that in the beginning of 1990s, the model began to be more challenged (Kalinic et al., 2012) and is not the most appropriate method of analysing a firm's internationalization (Górska, 2013; p. 3) behaviour due to the significant changes and developments in the business world, such as technological advancement. As a result, the authors of the Uppsala model resolved to revise the theory and ultimately shift the focus of the model to put more emphasis on the significance of business networks. The core argument of the revised Uppsala model is that markets are made up of a network of relationships, therefore, gaining insidership in the relevant networks is significant (Ribeiro-Soriano \& Urbano, 2009) for successful internationalization. The relationships formed by the entrepreneurs provide an opportunity for them to learn, create trust, and build commitment. This implies that a firm's business network is largely responsible for shaping its foreign business.

\section{DISCUSSION}

\section{Implications}

Studies conducted on different firms have demonstrated the effectiveness of the internationalization model. A survey conducted by Galkina and Chetty (2015) revealed that networking activities are crucial in the process of internationalization. This survey also established that network relations mostly drive the whole expansion process. The formulation business networks are vital in giving an organization (Seltzer \& Bentley, 1999) insider-ship in the foreign market. Gaining insiders is crucial in the process of internationalization since it allows an organization to access first-hand information on the industry. Over the years, there have been many changes in business environment due to several aspects, such as technological advancements that have consequently increased the world's interconnectedness. These changes 


\section{International Journal of Business Management and Economic Review}

Vol. 4, No. 05; 2021

ISSN: 2581-4664

bundled with the assumptions and methods used in the Uppsala model have created challenges for entrepreneurs when trying to use it.

The human attributes such as language, culture, managerial experience, education, and foreign experience also play a significant role in determining the best strategy that can be used to guide the business expansion. However, it is recommended for new ventures to utilize the concepts of the modified Uppsala model to not only create uniqueness in their business model but also steadily expand to foreign markets. Creating collaborations with global partners is one of most challenging tasks to accomplish in internationalization entrepreneurship. Nonetheless, it is a practice that can be accomplished and practiced.

Understanding entrepreneurial internationalization implicates that the internationalization process substantially depends on the idealization of specific factors. These factors include international entrepreneurship, education and training, human capital, changing dynamics of the markets, sustainability status, market demands, time, strategies, and external pressures. Other than that, sufficient identification of internationalization models and strategies create more alternatives for the entrepreneurs to expand the business entities into target foreign markets (Gabrielsson et al., 2014).

\section{Future research}

One of the main assumptions that pose challenges for entrepreneurs when using Uppsala model is assuming that a business or company must start developing in the domestic market before expanding to a foreign market. However, this has not been the case in the modern business environment since some entrepreneurs have managed to set up businesses in foreign markets and have been successful even before venturing into their local markets. For instance, there has been a trend in the music industry, where musicians launch their music in other countries like Japan before launching them in their home countries (Zohari, 2012). Therefore, there is a huge need for further research to determine how the Uppsala model can be modified to acknowledge the fact that not all businesses are established in their home countries and also for the model to be flexible to the modern trends.

Researching the market potential is also very important in determining whether the business expansion is worth it or not. For instance, if an entrepreneur selling pig products decides to use the Uppsala model to move to an Islamic country and only focuses on the psych distance. Then he/she is likely to expand his/her business into the Islamic country and eventually fail since Muslims do not eat pork products. Therefore, it is highly important to conduct further studies on the influence of other market factors such as market potential, culture of the target market, and budgetary issues to determine the best possible expansion strategy.

\section{Limitation}

The initial Uppsala model stated that companies and businesses should expand to markets with shorter psych distance since the chances of success in those markets are higher than in markets with a higher psych distance. However, with the advancement of technology, getting market information from any country has become very easy (Zohari, 2012). For instance, if entrepreneurs want to internationalize their business, they can easily research various market 


\section{International Journal of Business Management and Economic Review}

Vol. 4, No. 05; 2021

ISSN: 2581-4664

information such as the country's consumer trends and the cultural and religious beliefs in the target market. Entrepreneur can also use social media channels such as Instagram and Facebook to study people's buying trends and preferences in the target market (Zohari, 2012). Therefore, with the advancement of technology, it has become easy for entrepreneurs to gather knowledge of new process, products and market (Shane, 2000) in the world regardless of the psych distance between the target market and the domestic market.

The Uppsala model disregards other effective forms of market entry, such as franchising and licensing. Franchising is defined as a relationship between the franchisor, who is the entrepreneur, and the franchisee. The franchisor grants the franchisee licensed privilege to conduct the business and cater to all the business needs in return for money (Zohari, 2012). An entrepreneur can also decide to use this market entry model by granting a citizen of the country with licensed privileges over the business and monitor the outcomes through which they can gauge whether the move is a wise decision for the business or not.

Another effective method of market entry that the Uppsala model disregards is licensing. In licensing, the entrepreneur grants a company in a foreign country permission to manufacture their products for a given amount of money. Therefore, the entrepreneur will not incur the expenses associated (Zohari, 2012). In general, it is important to highlight that if Uppsala model took notice of less risky forms of market entry such as franchising and licensing, then there would be few challenges that the entrepreneurs would face during the internationalization process.

The model also poses challenges due to its sole focus on the internationalization process as an internal capability development (Welch et al., 2014). By doing this, the model ignores other important factors such as competitive forces and market potential, which override the element of psych distance (Zohari, 2012). Competition and the prior knowledge of the markets are the most critical factors that an entrepreneur should focus on before entering a foreign market (Shane, 2000). If the competition or prior knowledge is stiff, then there are possibilities of not succeeding in that market. However, easy access to market information does not guarantee smooth and successful entry to international market (Welch et al., 2016). Therefore, if an entrepreneur uses the Uppsala model and only focuses on psych distance, they might lose their business in a highly competitive market.

Finally, the Uppsala model fails to address the internationalization process from the viewpoint of the service sector (UKEssays, 2018; Andersen, 1993). If an entrepreneur deals with services instead of goods, what are the processes they must follow when expanding into foreign markets (Carneiro et al. 2008)? All the model's steps focus on the internationalization of a business dealing with goods. Therefore, it can be challenging for an entrepreneur dealing with a servicebased industry to effectively use the Uppsala model. Furthermore, first part of Uppsala model (1977) considered the most outdated model (Welch, Nummela \& Liesch, 2016) and fails to highlight suitable methods that modern firms can leverage (UKessays, 2018) to accumulating foreign market knowledge. Instead of gaining experience only through activities in the market, the entrepreneur can use alternative methods such as strategic imitation where an entrepreneur purposefully copies products, market entry methods used by other entrepreneurs, and managerial methods to successfully operate in the foreign market (Dikova \& Brouthers, 2016; Zohari, 2012). 


\section{International Journal of Business Management and Economic Review}

Vol. 4, No. 05; 2021

ISSN: 2581-4664

Another effective way of gaining knowledge disregarded by the Uppsala model is learning from grafting. Nonetheless, credit has to be given to the creators of the model since they have significantly contributed to the efforts of addressing internationalization problems and simplifying the process.

\section{CONCLUSION}

In summary, the concepts of the initial Uppsala model cannot be applied in the modern business environment. The reason is that the modern business environment is characterized by rapid technological advancements that have significantly transformed the internationalization process. Therefore, it is highly recommended for new business ventures to adopt the concepts of the modified version of the Uppsala model when looking to expand to foreign markets. The internationalization process theory and business network theory played a significant role in defining the role of the Uppsala model in the internationalization process, as well as the influence of the revised Uppsala model in bolstering business networks. These theoretical frameworks not only establish the importance of the Uppsala model in the modern business environment but also reinforced the need for adjusting the model to keep up with the latest market trends.

Additionally, the paper focused on the need for organizational leaders and managers to adopt the appropriate Uppsala model. Firms existing in the modern business environment are expected to put more emphasis on social connections and business networks (Zhukova, 2017). This is because the existing markets are made up of a network of relationships. One of the key limitations of this study is that it has a limited scope since it is only based on qualitative research analysis. The study heavily depends on the information highlighted in the previous literature regarding the applicability of the Uppsala model. Therefore, there is a huge need for future researchers to conduct a quantitative research analysis on the applicability of the Uppsala model to obtain a greater understanding of the significance of this model in the modern business environment.

\section{REFERENCES}

Acs, Z. J., McMullen, J. S. \& Plummer, L. A. (2007). What Is an Entrepreneurial Opportunity? Small Business Economics 28(4), pp 273-283.

Ahmad N., and Seymour Richard G. (2008). 'Defining Entrepreneurial Activity: Definitions Supporting Framework for Data Collection.' OECD Statistics Working Paper.

Alexey Zhukov. 'Opportunity and Business Service'.

Andersson, S. (2006). International Growth Strategies in Consumer and Business-to-Business Markets in Manufacturing and Service Sectors. Journal of Euro marketing, 15(4), pp 49.

Andonova, L. B. (2017). Governance entrepreneurs: International organizations and the rise of global public-private partnerships. Cambridge University Press.

(Aulakh, P.S., Kotabe, M. and Sahay, A. (1996), Trust and Performance in Cross-border Marketing Partnerships: A Behavioral Approach. Journal of International Business Studies, 27(5), pp. 1005-1015. 


\section{International Journal of Business Management and Economic Review}

Vol. 4, No. 05; 2021

ISSN: 2581-4664

Autio, E. (2017). "Strategic entrepreneurial internationalization: A Normative Framework." Strategic Entrepreneurship Journal. 11(3).

Baker T., Gedajlovic E. and Lubatkin M. (2005). "A Framework for Entrepreneurship Process across Nations." Journal of International Business Studies, 36, pp 492-501.

Belitski, M., \& Heron, K. (2017). Expanding entrepreneurship education ecosystems. Journal of Management Development, 36(2), pp 163-177.

Beugelsdijk S., Kostova T., Kunst V.E., Spadafora E., \& van Essan M., (2018). Cultural Distance and Firm Internationalization: A Meta-Analytical Review and Theoretical Implications. Journal of Management, 44(1), pp 95-99.

Birkinshaw, J. and Redderestråle, J. (1999). "Fighting the Corporate Immune System: A Process Study of Initiatives in Multinational Corporations. "International Business Review 8. pp 149166.

Boone, C., Lokshin, B., Guenter, H., \& Belderbos, R. (2018). Top Management Team National Diversity, Corporate Entrepreneurship, and Innovation in Multinational Firms. Strategic Management Entrepreneurship Journal, 40(2), pp 227-302.

Butuner, H. (2016). Redesigning Scenarios and Defining Business Opportunities. Journal of International Business and Social Research, 6 (4), pp 4-8.

Carneiro, J., Rocha, A., \& Silva, J. (2008). Challenging the Uppsala internationalization model: a contingent approach to the internationalization of services. BAR - Brazilian Administration Review, 5(2), 85-103. https://doi.org/10.1590/s1807-76922008000200002

Cavusgil, S.T., \& Knight, G. (2015). The Born Global Firm: An Entrepreneurial and Capabilities Perspective on Early and Rapid Internationalization. Journal of International Business Studies, 46(1), pp 3-16.

Ciszewska, M.M. (2016). Foreign Market Knowledge and SME's International Performance: Moderating Effects of Strategic Intent and Time-to-Internationalization. Entrepreneurial Business and Economics Review 4(4), pp 51-66.

Coviello N.E. and Jones M.V. (2015). "Is International Entrepreneurship Research a Viable Spin-off from its Parent Disciplines?"

Coviello, N. (2006). The Network Dynamic of International New Ventures. Journal of International Business Studies, 37, pp 714-715.

Coviello, N., Kano, L., \& Liesch, P. W. (2017). Adapting the Uppsala Model to A Modern World: Macro-Context and Microfoundations. Journal of International Business Studies, 48(9), pp 1151-1164.

Ciszewska-Mlinarič, M.; Trapczyński, P. (2016). The psychic distance concept: A review of 25 years of research (1990-2015). J. Man. Bus. Adm. Cent., 24(2), 2-31.

Cunningham, J.B. \& Lischeron, J. (1991). Defining Entrepreneurship. Journal of Small Business, pp 45-54. 


\section{International Journal of Business Management and Economic Review}

Vol. 4, No. 05; 2021

ISSN: 2581-4664

Dikova, D. \& K. Brouthers (2016). International Establishment Mode Choice: Past, Present and Future. Management International Review, 56(4), pp 489-530.

Dunning, J. (2001). The key literature in IB activities. In: A. Rugman and T. Brewer (ed.), The Oxford Handbook of International Business, Oxford.

Fadahunsi, A. (2012). The Growth of Small Businesses: Towards A Research Agenda. American Journal of Economics and Business Administration 4 (1), pp 110-113.

Gabrielsson M., Gabrielsson, P. \& Dimitratos, p. (2014). International Entrepreneurial Culture and Growth of International New Ventures. Management International Review, 54:445-47.

Galkina T. \& Chetty, S. 2015 Effectuation and Networking of Internationalizing SMEs. Management International Review, 55 (5), 647-676.

Górska, M. (2013). DOES THE UPPSALA INTERNATIONALIZATION MODEL EXPLAIN THE INTERNATIONALIZATION PROCESS OF PROFESSIONAL BUSINESS SERVICE FIRMS? CBU INTERNATIONAL CONFERENCE ON INTEGRATION AND INNOVATION IN SCIENCE AND EDUCATION, pp. 1-8. DOI: 10.12955/cbup.2013.8.

Hindle, K. (2004). A Practical Strategy for Discovering, Evaluating and Exploiting Entrepreneurial Opportunities: Research-based Action Guidelines. Journal of Business and Entrepreneurship. 17 (4) pp. 267- 276.

Huo, D., Hung, K. (2015). "Internationalization Strategy and Firm Performance: Estimation of Corporate Strategy Effect Based on Big Data of Chinese IT Companies in a Complex Network" Romanian Journal of Economic Forecasting - XVIII (2).

Hollsten, L. (2016). Framework for an International Strategy. (Degree Thesis for Bachelor of Business Administration, Turku), pp 1-5.

Hombrecher, C. (2014). The Uppsala model of internationalization. A critical review, Munich, Grin Verlag. https://www.grin.com/document/458052

Hsieh, C., Nickerson, J.A. \& Zenger, T.R. (2007). Opportunity Discovery, Problem Solving and a Theory of the Entrepreneurial Firm. Journal of Management Studies, 44(7), pp 1256-1258.

Jafari-Sadeghi, V., Dutta, D.K., Ferraris, A. and Del Giudice, M. (2020), "Internationalisation business processes in an under-supported policy context: evidence from Italian SME. Business Process Management Journal, 26 (5), pp.1055-1074.

Johanson, J. and Vahlne J.-E. (2009). "The Uppsala Internationalization Process Model Revisited: From Liability of Foreignness to Liability to Outsiders." Journal of International Business studies. Pp 1411-1431.

Johanson, J., E Vahlne, J. (2002). "The Internationalization Process of the Firm: A Model of Knowledge Development and Increasing Foreign Market Commitments." Journal of International Business Studies. Vol. 8

Jones, M. \& Coviello, N. (2005). Internationalization: Conceptualising An Entrepreneurial Process of Behavior on Time. Journal of International Business Studies 36, pp 284-289. 


\section{International Journal of Business Management and Economic Review}

Vol. 4, No. 05; 2021

ISSN: 2581-4664

Jones, M.V., Coviello N. and Tang Y.K. (2011). "International Entrepreneurship Research (1989-2009): A domain ontology and thematic analysis." Journal of Business Venturing, pp 632635.

Kalinic, I. \& Forza, C. (2012). Rapid internationalization of traditional SMEs: Between gradualist models and born globals. International Business Review, 21 (4), pp. 694-707,

https://doi.org/10.1016/j.ibusrev.2011.08.002.

Kauppinen, A. \& Puhakka, V. (2010). Creating entrepreneurial opportunities: an organizational and social constructive phenomenon in the creation of new businesses. International Journal of Entrepreneurial Venture, 1(4), pp 439.

Kraus, S., Mensching, H., Calabro, A., Cheng, C.F., Filser, M. (2016). Family form Internationalization: A configurational approach. Journal of Business Research, 69(11), pp 54735478.

Kularia, A. (2016). Guest writer, 'Luck and entrepreneurship: Is there a connection?

Lee, S.H. and Williams C. (2007). "Dispersed Entrepreneurship within Multinational Corporations: A community perspective." Journal of World Business. Pp 505-517.

Lehtoranta, O., Rilla, N., \& Loikkanen, T. (2012). Internationalization of Knowledge and Innovation Activities in Finnish Innovation and SMEs. Innovations, Economy and Policy, VTT, pp 8-20.

Machado, H.P.V. (2016). Growth of small businesses: a literature review and perspectives of studies. 23(2), pp 420-424.

Mainela, T., Puhakka V. and Sakari S. (2014). International Entrepreneurship Beyond Individual and Firms: On the Systemic Nature of International Opportunities. Journal of Business Venturing, 33(4), pp 535-537.

Mainela, T., Puhakka V. and Servais P. (2014). "The Concept of International Opportunity in International Entrepreneurship: A Review and a Research Agenda." International Journal of Management Reviews. 105-110, pp 116-122.

Malecki, E.J. (2018). Entrepreneurship and entrepreneurial ecosystems. Geography Compass, 12 (3), pp. 1-21.

McDougall, P.P. (1989). "International versus Domestic Entrepreneurship: New Venture Strategic Behaviour and Industry Structure," Journal of Business Venturing, 4(6), pp 387- 400.

Mueller, S., Volery, T. \& Von Siemens, B. (2012). What Do Entrepreneurs Actually Do? An Observational Study of Entrepreneurs' Everyday Behavior in the Start-Up and Growth Stages. Entrepreneurship: Theory \& Practice, 36: 995-1017.

Ojala, A. and Tyrväinen, P. (2009). Impact of psychic distance to the internationalization behavior of knowledge-intensive SMEs. European Business Review, 21(3): 263-277, http://dx.doi.org/10.1108/09555340910956649. 


\section{International Journal of Business Management and Economic Review}

Vol. 4, No. 05; 2021

ISSN: 2581-4664

Ojala, A., \& Puhakka, V. (2013). Opportunity Discovery and Creation in Cloud Computing. In 46th Hawaii International Conference on System Sciences, 24 (8), pp. 4294- 4303.

Oviatt, B.M. \& McDougall, P.P. (2005). Defining International Entrepreneurship and Modelling the Speed of Internationalization, Entrepreneurship, Theory \& Practices, 29, pp 539.

Oviatt, B.M., \& McDougall-Covin, O. (2015). International Entrepreneurship. Wiley Encyclopedia of Management, 1-3.

Pukall, T.J. and Calabro, A. (2014), "The internationalization of family firms: a critical review and integrative model", Family Business Review, Vol. 27 No. 2, pp. 103-125.

Rani, P. (2019). Strategy Implementation in Organizations: A Conceptual Overview. Management, 14 (3), pp 205-218.

Ratten, V., Ramadani, V., Dana, L.P., Hoy, F., \& Ferreira, J. (2017). Family Entrepreneurship and Internationalization Strategies. Review of International Business and Strategy, 27(2), pp 150-160.

Reuber, A. R., Knight, G.A., Liesch, P.W., \& Zhou, L. (2018). International Entrepreneurship: The Pursuit of Entrepreneurial Opportunities across National Borders.

Ribeiro, S.D. \& Urbano, D. (2009). Overview of Collaborative Entrepreneurship: An Integrated Approach between Business Decision and Negotiations. Group Decision and Negotiation, 18(5), pp 419-430.

Ruzzier, M., Rus, M., \& Douglas, E. J. (2015). Global entrepreneurial orientation, inward internationalization, and business survival (Doctoral dissertation, Univerza na Primorskem, Fakulteta za management).

Saskia De Klerk (2014). The creative entrepreneur or the entrepreneurial creator. Conference: Australian Centre for Entrepreneurship At: Sydney, pp 1-4.

Sandberg, S. (2012) INTERNATIONALIZATION PROCESSES OF SMALL AND MEDIUMSIZED ENTERPRISES Entering and taking off from emerging markets. ISBN: 978-91-86983$35-2$.

Shane, S. and Venkataraman S. (2000). The Promise of Entrepreneurship as a Field of Research. Academy of Management Review.

Shane, S. (2000) 'Prior Knowledge and the Discovery of Entrepreneurial Opportunities', Organization Science 11: 448-469.

Seltzer, K., \& Bentley, T. (1999). The creative age: knowledge and skills for the new economy: Demos.

Tang, J., Kacmar, K.M., \& Busenitz, L.W. (2012). Entrepreneurial alertness in the pursuit of new opportunities. Journal of Business Venturing, 27, 77-94.

Ucbasaran, D., Wright, M., \& Westhead, P. (2010). The Internationalization of SMEs and International Entrepreneurship: A Critique and Policy Implications.

UKEssays. (2018). Uppsala Model and the Network Approaches to Internationalisation. International Studies. 
International Journal of Business Management and Economic Review

Vol. 4, No. 05; 2021

ISSN: 2581-4664

Wach, K. (2015). Entrepreneurial Orientation and Business Internationalization Process: The Theoretical Foundation of International Entrepreneurship. Entrepreneurial Business and Economics Review, 3(2), pp 9-24.

Welch, C. \& Paavilainen-Mäntymäki, E. (2014). Putting Process (back) In: Research on the International Process of the Firm. International Journal of Management Reviews, 16 (1), pp 223.

Welch, C., Nummela, N. \& Liesch, P. (2016). The Internationalization Process Model Revisited: An Agenda for Future Research. Management International Review, 56 (6), pp 783-804.

Zander, I., McDougall-Covin, P. \& Rose, E.L. (2015). Born Globals And International Business: Evolution of A Field of Research. Journal of International Business Studies, 46 (1), pp. 27-35.

Zhukova, E. (2017). Sales Management in Foreign Markets: Case Study on Finnish Companies' Knowledge Management in Russia. Master's Thesis in International Business, Turku, pp 37-39.

Zucchella, A., \& Magnani, G. (2016). International Entrepreneurship: Theoretical Foundations and Practices. Springer. 